\title{
Poetics of the Symbolist “Text-myth” by Andrey Bely
}

\author{
Anna Igorevna Oshchepkova \\ North-Eastern Federal University in Yakutsk, 58 Belinsky Street, Yakutsk, Russia, 677000
}

First published September 30, 2019

\begin{abstract}
:
The article discusses the peculiar poetics of Andrey Bely's symbolist "novel-myth". The mythological-poetic structure of "The Silver Dove" as a symbolist "text-myth" implies a special type of narration oriented towards heterogeneous artistic language. Andrey Bely's short novel is characterized by complex narrative architectonics based on stylization and orientation to the third party's speech.
\end{abstract}

Keywords: symbolist "text-myth", Andrey Bely, poetics, narration, stylization.

\section{INTRODUCTION}

The first "large-scale narrative work" by Andrey Bely (Lavrov, A.V., 1995, p. 563) "The Silver Dove" represents a new stage in the development of a great epic form. Andrey Bely defined the genre of his work as a short novel, while most scholars considered it as the first experience in writing the novelistic form (L.K. Dolgopolov, L. Silard). This literary work is among the most ambiguous and at the same time little-studied pieces of A. Bely. The insufficient study of this short novel can be explained by the fact that it was overshadowed by the novel "Petersburg". "The Silver Dove" is mainly analyzed in literary criticism from the historical and philosophical viewpoints. Modern scholars consider "The Silver Dove" in the context of A. Bely's literary evolution as the work that played an intermediate and even secondary role in laying the ground for his masterpiece "Petersburg" (L. Dolgopolov, A.V. Lavrov, S. Piskunova and V. Piskunov). Unfortunately, this short novel has not been adequately studied from the perspective of poetics and stylistics, but some researchers indicate that there are folklore-mythological motifs and features of folklore stylization in "The Silver Dove" (Toporov, V.N., 1999; Kozmenko, N., 1992). However, these comments are mostly fragmentary and do not consider the general uniqueness of the literary work under consideration. Speaking about peculiarities of "neo-mythological" texts written by symbolists, Z.G. Mints notes that "The Silver Dove" along with "Petersburg" and "The First Encounter" are symbolist "text-myths". The author's remarks are extremely important in this short novel and state that the "prosaic" novel-myth runs like a golden thread through all the works of V. Bryusov, A. Bely, F. Sologub, A. Remizov, etc. and ends with "Petersburg" (classic "neo-mythological" work) where all the features of the "novel-myth" are not only realized but also experimentally emphasized and become (typical of all mature forms of this genre) the object of a unique artistic game" (Mints, Z.G., 1994, p. 96). Considering the internal connection of Blok's stylistics with "The Silver Dove", V.N. Toporov emphasizes that the short novel contains many mythological-poetic elements. Therefore, "the text is likely to be read in such a way that would clarify certain "eidetic" patterns, narrative and compositional techniques and language "shibboleths" known outside ща (c) AesthetixMS 2019. This Open Access article is published under a Creative Commons Attribution Non-Commercial 4.0 International License (http://creativecommons.org/licenses/by-nc/4.o/), which permits non-commercial re-use, distribution, and reproduction in any medium, provided the original work is properly cited. For citation use the DOI. For commercial re-use, please contact editor@rupkatha.com. 
this style" (Toporov, V.N., 1999, p. 257). In the framework of these two authoritative statements, it is possible to conclude that "The Silver Dove" was the first A. Be-ly's experiment in creating his own prosaic "novel-myth".

\section{METHODS}

A. Bely's type of narration is heavily influenced by N. Gogol's literary traditions. Moreover, the very idea of folklore stylization is also formed in conformity with N. Gogol's poetics (E.G. Mushchenko, V.P. Skobelev, L.Ye. Kroichik). While considering the history and poetics of taleand fairy-tale-like forms in the Russian literature, researchers determine several types of narrators in A. Bely's "Silver Dove": a rural storyteller, a county storyteller of the aristocratic origin, etc. N.A. Kozhevnikova has a different point of view and highlights that "A. Bely's tale is built as a transformed quotation from N. Gogol's works". N. Gogol often speaks through several storytellers but A. Bely uses a "conditional narrator" who acts as "an all-knowing author and a narrator close to the depicted environment" (Kozhevnikova, N., 1992, p. 66). N.A. Kozhevnikova's viewpoint seems to be the most precise in defining the peculiarity of the narration in this work. In this regard, it is necessary to analyze the structure of narration in A. Bely's "Silver Dove" in its correlation: a) with genre traditions of the folklore origin and b) the narrative manner of oral origin dating back to folklore.

\section{RESULTS}

The mythological-poetic structure of "The Silver Dove" as a symbolist "text-myth" sug-gests a special type of the narration focused on heterogeneous artistic language. In this sense, the polygeneticity of symbolist texts implies the conscious orientation of the narration to folkloremythological and literary traditions that, first, should be recognized by "their reader", second, heterogenetic components of the author's speech should emphasize their "diversity and mutual incompatibility", third, the polysemantic narration should form the integral structure of the socalled "unified Myth" (Mints, Z.G., 2004, p. 74).

\section{DISCUSSION}

In the article "Gogol" (1909) published in the fourth issue of the "Libran" journal along with one of the chapters from "The Silver Dove", A. Bely wrote: "Who does not remember an amazing story about Captain Kopeikin, but please look closer at the technical side of this method: a trite presentation of misfortunes experienced by the miserable captain is interrupted each two words with such expressions as "if you please", "so to speak", etc. This rude technique helps Gogol achieve dazzling expressiveness. N. Gogol's style is pre-cultural but surpasses in its refinement Wald, Rambo, Sologub and other "decadents", including Nietzsche himself" (Bely, A., 1994, p. 144). Although the genre of tale was not named or defined terminologically, A. Bely paid much attention to it. He highlighted the principle of "two-voice" narration: on the one hand, the narrator's speech is "trite" or "cultureless"; on the other hand, "N. Gogol's creative style" is refined. For A. Bely, this dual construction of the author's literary idiolect was the evidence of N. Gogol's verbal mastery. In this case, A. Bely's position as a researcher of N. Gogol's literary works and the author of the short novel is the same. N. Gogol's influence on the narration in "The Silver Dove" can be traced from the very beginning. It is especially noticeable when the author gives word to his common narrator. 
N. Gogol wrote: "A wonderful town is Mirgorod! How many buildings are there with straw, rush, and even wooden roofs! On the right is a street, on the left a street, and fine fences everywhere. Over them twine hop-vines, upon them hang pots; from behind them the sunflowers show their sun-like heads, poppies blush, fat pumpkins peep; all is luxury itself!" (Gogol, N.V., 1966, p. 234).

A. Bely provided the following description: "It is a fine village, Tselebeyevo, not far from the town, surrounded by hills and meadows; its scruffy cottages, scattered here and there, are richly decorated, one with a carved frieze like a real lady of fashion with curls all over, another with a painted tin cockerel, others with crudely painted flowers and angels; it is finely adorned with wattle fences, hutches and pens, the odd currant bush, and a whole host of starling-cotes that stand out against the twilit sky on their crooked broomsticks: a fine village!" (Bely, A., 1988, p. 21).

There is an obvious correlation between N. Gogol's description of Mirgorod and A. Bely's depiction of Tselebeyevo ("A wonderful town is Mirgorod" - "It is a fine village, Tselebeyevo"). A. Bely once noted that N. Gogol's style is characterized by "piling-up." It should be noted that N. Gogol based his description on dynamic worldview: first, he drew a general plan ("How many buildings are there!"), then he looked down from the top starting from the roofs and going down to the pumpkins.

A. Bely used the same description as N. Gogol did: the same circular composition "it is a fine village, Tselebeyevo" at the beginning and "a fine village" at the end of the text; the same dynamic manner of seeing things - from top to bottom, a general view at first, then the narrator's gaze moves from the house to the currant bush under the fence.

N. Gogol's narrator forms his speech based on the following principle: the structural description of Mirgorod consists of three parts: the first part - the roofs are mentioned, the second part - the streets are indicated, the third part - the fence is described. Each part is built on the same triple principle: "with straw (1), rush (2), and even wooden roofs (3)"; "on the right is a street (1), on the left a street (2), and fine fences everywhere (3)". A. Bely structurally repeated N. Gogol's style of storytelling. The description of the village of Tselebeyevo corresponds to the indicated triple narration: "its scruffy cottages, scattered here and there" (1); "it is finely adorned with wattle fences"(2); "and a whole host of starling-cotes" (3). Each description also has a triple system: cottages are decorated "with a carved frieze..." (1); "with a painted tin cockerel..." (2); "with crudely painted flowers..." (3).

However, the narrator's position in "The Silver Dove" fundamentally differs from that in N. Gogol's "Evenings on a Farm Near Dikanka". N.A. Kozhevnikova sees the difference in the fact that A. Bely connected "everyday tale and romantic narrative" in contrast to N. Gogol who assigned it to different storytellers and replaced them with "a conditional narrator combining the functions of the all-knowing author and narrator close to the depicted environment" (Kozhevnikova, N., 1992, p. 66). A. Bely's image of the narrator is complex and distinctive; it is a combination of a literary author and a fictional narrator. The story creates a narrator who acts as a storyteller close to the portrayed environment and involved in its life and life of local people. In this case, the narrator chang-es various masks: he can be an all-seeing and all-knowing author, a person from the village of Tselebeyevo, a storyteller of the aristocratic origin or a county resident of the town of Likhov.

A. Bely's narrator is more wary of "strangers" than N. Gogol's: "... we have had visits from the likes of you often enough and we are not easily impressed by anyone any more. Do not turn up your noses, there is no point" (Bely, A., 1988, p. 15). The speech of A. Bely's narrator is characterized by the frequent use of vernacular. The chosen type of narration naturalistically reproduces phonetic 
features of someone else's speech, which is common to the stylized tale-like manner of narration. It contains signs of colloquial speech: "And then we are known as Doves: and we fly all over, across the whole district"; "Go, if you like, roads are public here"; "... he is no longer a socialist", "Cult-ists, that's it!"; "Well, I'll show you some diamonds...", etc. (Bely, A., 1988, p. 137-145, 169). These signs often utilize syntactic figures typical of oral speech. The most frequently used is inversion when an adjective follows a noun: "... I would like to take a chair, a wooden one, you know"; "... free, so you say, people ..."; "You are a fine wench, big-eyed, well-grown"; "He had a wonderful woman, freckled" (Bely, A., 1988, p. 135-207). This construction was also used by N. Gogol: "Wonderful are the turnips we have grown in the garden". A. Bely referred to such common figures of oral speech as elliptical constructions: "- Kha! Ugh! Oh, damn! - and the peasants left"; "A groan under the very ear - is it an owl?"; "Lo and behold, but everything is different" (Bely, A., 1988, p. 230-232). A. Bely's narrator lacks in some cases narrative simplicity. Promising to feed guests and give them a drink, the narrator sharply remarks: "... if you do not want it, God will judge you: residents of Tselebeyevo will do without you" (Bely, A., 1988, p. 30-31). The narrator is well-informed about nearby sights. As a local watchman, he advises to check out frescoes of the local church where newly arrived icon-painters depicted "some man" resembling the shopkeeper of Tselebeyevo - Ivan Stepanov. Anticipating some distrust, the narrator hopes that he will be believed and "the stranger" will become "one of the people", otherwise there is no sense in telling such a story: "Well, I am blowed: did you take it into your head to smile? If you come into the church, I will show you the man straight away: that righteous man is still there to this day, painted to the right of the iconostasis (you can see for yourselves). Well, you can believe me anyway!" (Bely, A., 1988, p. 37). The narrator waits for the expected response.

In this case, the narrator retells things known by any resident of Tselebeyevo: about the portrait likeness of the local shopkeeper and the icon. The narrator's viewpoint merges with that of residents of Tselebeyevo, he speaks on his own behalf and on behalf of all its inhabitants. This community also includes the listener who becomes "one of them" instead of the "stranger": the narrator purposefully retells stories well-known by all the residents of Tselebeyevo.

The mask of the rural narrator is not the only one in the narrative system of "The Silver Dove". The mask of the village narrator is often replaced with the mask of the county narrator, the inhabitant of the town of Likhov: "... no one had suffered any ill at her hands (the wife of a rich miller Fyokla Matveyevna Yeropegina), and she had done a lot of good for widows and old women: there was a home for old women just nearby on Panshin Street. She was a kind soul, was Fyokla Matveyevna, and her husband, Luka Silych, should have been ashamed of making fun of her like that, he really should! What kind of a dollop was she? Dollops do not have hearts like that, one look at her eyes was enough to tell you" (Bely, A., 1988, p. 88-89).

While the rural narrator combines complacency with distrust, the urban narrator is quite enthusiastic, i.e. he likes pathos and resembles the landowner of Mirgorod who sees all the people around as kind. Therefore, the narrator appeals to "lackeys" and ask them to admire the spiritual beauty of the so-called "dollop" and condemn her immoral spouse. The county narrator knows the town of Likhov, as well as the rural narrator, is familiar with the village of Tselebeyevo. Hence, the corresponding gesture is typical of his speech: "... here on Panshin Street ...", "they drank there, in a two-storey house..." (Bely, A., 1988, p. 121).

Both narrators do not reveal their political sympathies in any way. They and the people they represent are calm, secretive and are not inclined to generalization. In contrast to these two types of speech, one more mask appears. It is a man of conservative views, committed to aristocratic traditions, supported by his own community (political associates). The narrator with an 
aristocratic background addresses this audience and at the same time focuses on democratic environment taking into account its changes: "Yevseich! ... Where is there a butler like him: the very essence of a butler! Picture to yourself a butler: times have changed; and the butler, it may be said, has long since been facing extinction; the butler has dwindled to nothing; and if there is one still living somewhere, he must be very old; the butler in modern times has become decrepit, and if the desire takes you to employ a real butler, then be sure to look for an old one; anyone on the young side will not be a butler, but a thief or a boor, and even if he is not a boor, do you know who he is? - he is an independent person: he will grow a natty little moustache or some kind of beard, or else he will have moustache cut in a yankee style and dignify himself with the title 'comrade', or even 'citizen', no less; and, mark my words, a butler like that will not be with you even a year: he will run off to work in a restaurant, or some cheap and cheerful drinking place" (Bely, A., 1988, p. 146-147). This politically conservative narrator does not only gesticulate. Unlike the resident of Likhov, the narrator is inclined to acting and uses parodist intonations to reproduce the type of a modern serv-ant who is socially hostile to him.

The narrator complains about modern butlers and provides practical advice on hiring serv-ants to find full understanding with the audience. Like narrators from the town of Likhov and the village of Tselebeyevo, this one is among "his associates". The only difference is that the narrators from Likhov and Tselebeyevo have to hold the attention of their listeners, while in the latter case listeners are not just positively disposed but also considered as "friends". This audience can easily learn about others' political likes and dislikes. In this context, the rhetorical question "... do you know who he is?" plays the role of not a written but an oral appeal, becomes one more bridge connecting the speaker with listeners.

Speaking about the county or rural narrator, it is impossible to designate their narration to "bidirectional" or "unidirectional" types in conformity with M.M. Bakhtin's classification. Considering an ironic attitude to these narrators, their naivety and provincial narrow-mindedness, the author did not distinguish them within the framework of M. Bakhtin's classification. It is a different story with the narrator with a privileged background. The admiration for refined manners of Gudi-Guday-Zatrubinsky who did not really hide from authorities and came to local areas under the name of General Chizhikov; confidence in the justness of police investigations ("...in the station they will figure out who is right and who is wrong") (Bely, A., 1988, p. 187); complaints that "times have changed" and "the butler has long since been facing extinction"; fierce distrust of the young generation - all these factors create a cartoonish image of a conservative person. In its turn, this caricatural image emphasizes bidirectional narration and makes it one of the trends of the structure of "The Silver Dove".

The "bidirectional narration" connected with the speech of the narrator from privileged strata is opposed to the unidirectional narration represented by the narrators from the town of Likhov and the village of Tselebeyevo. The bidirectional narration in "The Silver Dove" is verbally distinguished by an abundance of foreign words denoting various fashionable items unfamiliar to common people. In addition to political conservatism, this literary technique consolidates the social status of the person opposed to the majority.

Thus, "The Silver Dove" is characterized by three types of speech masks expressing a certain social group. In the meantime, each type of narrators in "The Silver Dove" aspires to individualization. In this respect, there is unreasonable slander of the narrator from Tselebeyevo in relation to the local teacher: "Her blouses are dirt-cheap! Cotton or calico at 12 kopecks a yard; as soon as they are washed they come out in stains all over (the girls are always poking fun at her); if she sees a good-looking lad, or if a holiday-maker turns up, she will lift her skirts (showing her laddered 
stocking) and twirl her toe, with her eyes full of the joys of spring" (Bely, A., 1988, p. 39). Inner monologue does not imply the listener and is not aimed directly at the audience. However, inner monologue can fall within the sphere of narration and become its part. For instance, the voice of Styopka Ivanov, the son of the shopkeeper from Tselebeyevo, was conveyed in the following manner: "...he had caught his parent in a downright villainous act; the night before, when Styopka was loitering around Kudeyarov's cottage, he had clearly seen his parent, without his cap and wear-ing nothing over his shirt, fiddling around outside the cottage, dragging brushwood, pouring something from a bottle over it (kerosene, probably), and trying to strike a match; another moment - and the red cockerel would have risen above the carpenter's hut; well, of course, Styopka hissed at him: and his parent made himself scarce" (Bely, A., 1988, p. 113).

The narrator's speech is individualized because word is given to one of the characters: the narrator's direct speech is replaced by the character's inner monologue. As a result, the narrator's speech becomes the foundation of narration and repeats the story heard from Styopka. The tendency to dissolve the inner monologue of some character in the narrator's direct speech is preserved even when the narrator does not know the thoughts and feelings of the other person whose speech is transmitted. The authors recall the description of the wanderer Abram on the road to Tselebeyevo: "...there you sat in a hut, between four walls (if they would you let in for the night), amongst benches, women, children, hens, cockroaches and bedbugs; you sat and hid, or else you begged under windows; you might go on sitting there, just as before, by the peasant's kindness: and the same woman would bustle about, and the same children would swarm all over you, the same bedbugs. But here there were no children or bugs - just the free cold spirit that breathes upon you..." (Bely, A., 1988, p. 76). Although the wanderer is walking alone, it seems that the narrator is accompanying him. Thus, the narrator's position with the possibility of including in its speech mask of others' words is constructed as potentially redundant.

A conditional narrator, whose voice describes the village, its everyday life and inhabitants steps aside as soon as the subject changes. There is another narrator in the short novel, whose image is based on other principles. According to N.A. Kozhevnikova, this type of narrator "develops methods of lyrical storytelling" associated not with N. Gogol's "Evenings on a Farm Near Dikanka" but rather "Dead Souls" (Kozhevnikova, N., 1992., p. 68), in particular, a well-known lyrical description at the end of the first chapter. The same technique is used in A. Bely's narrative to describe lyrical fragments in the novel: "Oh, to live in the fields, to die in the fields, repeating to your-self the one spirit-strewing word, which no one knows but he who receives that word; and it is received in silence. Here amongst themselves they all drink the wine of life, the wine of a new joy - thought Piotr; the sunset here cannot be compressed into a book, and here the sunset is a mystery; in the West there are many books; in Russia there are many unspoken words. Many and many people are secretly burnt by the dream about field; oh, the Russian fields, the Russian fields! There you breathe the smell of resin, cereal and sea parsley: there is vastness to the Russian field where you can suffocate and die" (Bely, A., 1988, p. 203). The transition from inner monologue to outer speech is enhanced by the use of rhetorical exclamations, appeals and repetitions like "many", "the Russian field", alliterative-assonance consonances [ta], [po], [za], [mi], etc. These figures of poetic syntax and sound repetitions create the rhythm of the text typical of N. Gogol's lyrical narrator, which signals the presence of another narrator in the text. The imperceptible and fast change of the narration from the character's inner monologue to the outer plan of description serves as a mechanism for creating a syncretic narrator in A. Bely's novel, i.e. a means of forming different narrators. A similar method of creating a syncretic narration is found in the chapter "He remembered Gugolevo": "And he fell asleep: he dreamed of a girl's tender kisses, a sigh, and silver tears: it seemed to be the dew on his mother's grave, it seemed to be his mother herself: then it 
seemed she was a sister, friend, bride... " (Bely, A., 1988, p. 82). This phrase reveals the opposite phenomenon: the transition from external speech to inner monologue which is signalled by the appearance of an elliptical construction with a triple repetition "seemed to be", becomes dissonant, and as a result forms a sign of another consciousness.

\section{CONCLUSION}

Therefore, the speech masks of narrators in the author's structure of "The Silver Dove" reveal A. Bely's striving for stylization (imitation of the other's voice or folklore origin). A. Bely considered stylization as a means of creating a symbolist text. His narration is peculiar because A. Bely used $\mathrm{N}$. Gogol's model of narration to create his own narrative structure: the author's storyline is formed as a combination of the literary "narrator" and "folklore narrator", whose position goes back to the type of the folklore storyteller and is transformed by N. Gogol's tradition. In the second case, the narrator is mostly a storyteller with a typical narrative "manner". M.M. Bakhtin described this interpretation of the "folklore" or "oral" narrator: "The narrator is a non-literary person and in most cases belongs to the lower social strata, people (which is important to the author), and introduces an oral speech" (Bakhtin, p. 222-223). According to M. Bakhtin, a tale "is used to convey the voice of someone else or a special social group in order to introduce a number of viewpoints and assessments that the author needs" [ibid.]. The orientation to others' speech in tales is primary if compared to the orientation to the oral form of narration.

A. Bely formed a new syncretic image of the author and the type of the author's idiolect that combine both the narrator and storyteller who change different speech masks based on the principle of heterogeneity. In a broad sense, this heterogeneous construction of the narration in "The Silver Dove" means opposition to literary language and oral speech built over heterogeneous positions of "the literary narrator and storyteller which are opposed as "their own" and "alien". At the same time, the main principle of the author's narrative is a fairy-tale-like manner and the stylization of someone else's speech. In this case, the change of narrators is the "compositional substitution of the author's style" (M. Bakhtin). The dominant role of the author-narrator is constantly interpreted from the mythological (by different systems of myths) and folklore (as an oral, "alien" speech) perspective, which also creates the effect of the author's irony. The narrator (and various forms of its expression in the text) is included in the "composition of storytelling" (B.V. Tomashevskii) as one of the author's masks (one of the author's ironic expression forms), which makes the author quite conditional.

Thus, A. Bely created a complex architectonics of the narration defined by the stylization oriented towards others' word and narrative manner going back to folklore and Gogol's traditions. The type of narration typical of this short novel helps to disclose the poetics of the "novel-myth" in this literary work. A. Bely created a text based on folklore-mythological traditions and at the same time being parallel to them. The poetics of this creative work is determined by the process of synthesizing different folklore and mythological components. 


\section{REFERENCES}

Bely, A. (1994). Kritika. Estetika. Teoriya simvolizma [Criticism. Esthetics. The theory of symbolism]: in two volumes. Volume 1. Moscow, Iskusstvo.

Bely, A. (1988). Izbrannaya proza [Selected prose]. Compiled by L.A. Smirnova. Moscow, Sovetskaya Rossiya.

Bakhtin, M.M. (1974). Problemy poetiki Dostoevskogo [Problems of F. Dostoevsky's prose]. Moscow, Nauka.

Gogol N.V. (1966). Sobr.soch [Collected works]: in seven volumes. Volume 2. Moscow, Khudozhestvennaya literatura.

Kozhevnikova, N. (1992). Yazyk Andreya Belogo [Andrey Bely's creative language]. Moscow, Institut russkogo yazyka RAN.

Lavrov, A.V. (1995). Andrey Bely v 1900-e gody: Zhizn i literaturnaya deyatelnost [Andrey Bely in the 190os: Life and literary works]. Moscow, Novoe literaturnoe obozrenie.

Mints, Z.G. (2004). Poetika russkogo simvolizma [The poetics of the Russian symbolism]. Saint Petersburg: Iskusstvo.

Toporov, V.N. (1999). O "blokovskom" sloe v romane Andreya Belogo "Serebryanyi golub" [Blok's stylistics in Andrey Bely's novel "The Silver Dove"]. In: Moskva i "Moskva" Andreya Belogo. Moscow: Rossiiskii gumanitarnyi universitet. 